\title{
Fe and Fe-P Foam for Biodegradable Bone Replacement Material: Morphology, Corrosion Behaviour, and Mechanical Properties
}

\author{
Monika Hrubovčáková, Miriam Kupková, and Miroslav Džupon \\ Institute of Materials Research of SAS, Watsonova 47, 04001 Košice, Slovakia \\ Correspondence should be addressed to Monika Hrubovčáková; mhrubovcakova@imr.saske.sk
}

Received 29 July 2016; Revised 22 September 2016; Accepted 29 September 2016

Academic Editor: Michele Iafisco

Copyright (C) 2016 Monika Hrubovčáková et al. This is an open access article distributed under the Creative Commons Attribution License, which permits unrestricted use, distribution, and reproduction in any medium, provided the original work is properly cited.

\begin{abstract}
Iron and iron-phosphorus open-cell foams were manufactured by a replica method based on a powder metallurgical approach to serve as a temporary biodegradable bone replacement material. Iron foams alloyed with phosphorus were prepared with the aim of enhancing the mechanical properties and manipulating the corrosion rate. Two different types of Fe-P foams containing 0.5 wt.\% of $P$ were prepared: Fe-P(I) foams from a phosphated carbonyl iron powder and Fe-P(II) foams from a mixture of carbonyl iron and commercial $\mathrm{Fe}_{3} \mathrm{P}$. The microstructure of foams was analyzed using scanning electron microscopy. The mechanical properties and the corrosion behaviour were studied by compression tests and potentiodynamic polarization in Hank's solution and a physiological saline solution. The results showed that the manufactured foams exhibited an open, interconnected, microstructure similar to that of a cancellous bone. The presence of phosphorus improved the mechanical properties of the foams and decreased the corrosion rate as compared to pure iron foams.
\end{abstract}

\section{Introduction}

With an increasingly active lifestyle, accidents, obesity, and the growing age of population, the demand for orthopaedic solutions to bone repair, fractures, osteoporosis, and bone tumours keeps rising. A unique feature of bones is their ability to self-repair minor damage. Nevertheless, a more substantial damage requires an external intervention [1]. This is where both natural and synthetic bone grafts come in. Achieving optimal regeneration requires that the implanted scaffold material meets certain morphological and mechanical criteria. Ranking among the most significant morphological attributes of synthetic bone grafts are openness and the interconnectivity of the pore structure [2]. These provide channels for the transportation of the body fluids and stimulate the proliferation and attachment of new bone tissue. For porous bone substitutes, the optimal pore size for the attachment, differentiation, and growth of osteoblasts and vascularization has been found to range between 100 and $500 \mu \mathrm{m}$ [3]. Although metals like stainless steel, titanium, and titanium alloys are widely used in orthopaedic surgery because of their excellent mechanical properties [2-4], they, being nondegradable, remain in the body after tissue regeneration. Now, the presence of permanent implants or, to be more precise, the release of their metal ions can in the long run negatively affect the organism. Their removal, on the other hand, requires another surgery, which further burdens the patient and increases the cost of the treatment. Degradable biomaterials have recently proved to be capable of overcoming these drawbacks, as they can make for hard tissue scaffolds [5-7]. They have been introduced as a novel class of highly bioactive materials designed to disintegrate via corrosion after first providing temporary mechanical support for a period of time determined by the place of application [7]. Their greatest advantage is the fact that they require no removal surgery [8]. The literature on biodegradable materials usually pinpoints two metallic systems as particularly suitable, that is, magnesium-based and iron-based systems [8-13]. Magnesium is highly biocompatible and exhibits excellent conductivity and its mechanical properties are 


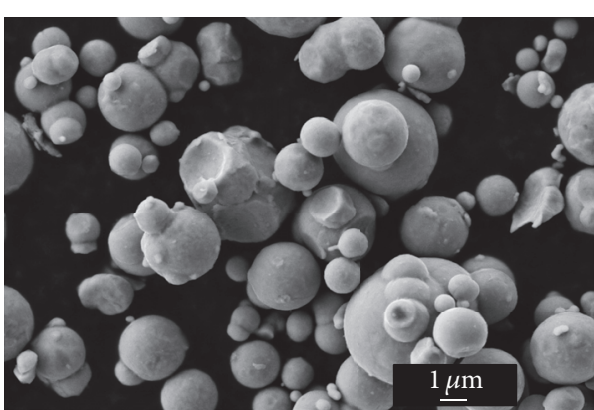

(a)

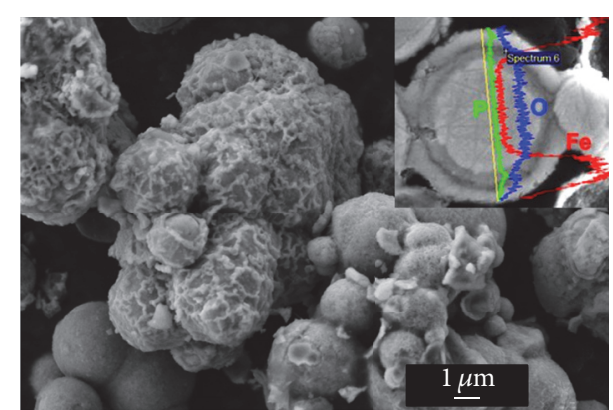

(b)

FIGURE 1: SEM image of carbonyl iron particles (a) uncoated and (b) as coated with a phosphate layer.

relatively similar to those of the human bone. Nevertheless, its degradation rate in combination with hydrogen evolution restricts its use in larger implants. Iron-based materials, being capable of combining high strength with a medium corrosion rate, are preferred when higher loads need to be carried [7]. The first in vivo tests revealed that although iron stents resorbed and caused no inflammatory reaction or changes in serum levels, their degradation rate was very low [10]. Much research was done to increase their degradation rate, for example, by alloying $[7,12]$, surface modification [14], and trying new fabrication methods [13].

Porous materials are especially promising in this regard, because, in addition to the reduction of stress shielding, they also allow the ingrowth of new bone tissue and the transportation of the body fluids $[15,16]$. More interestingly still, the porosity of cellular materials can be adjusted so as to match the strength and Young's modulus of the human bone. Biodegradable iron foams are most promising here, but the relevant literature offers little information on their use in tissue scaffolding. Few studies have focused on their biocompatibility, degradation rate improvement, and mechanical properties [17-22]. Products prepared from degradable iron and its alloys were found nontoxic and cytocompatible with various cell types, including endothelial [11], fibroblast [20, 21], mesenchymal [13], and smooth muscle [12] and also exhibited haemocompatibility with human blood [17].

In vitro cytotoxicity assessment of porous $\mathrm{Fe}-\mathrm{Mg}$ and $\mathrm{Fe}-$ CNTs and pure Fe manufactured by replica method showed a small osteoblast proliferation [18].

It generally holds that porous materials degrade faster than the compact ones. Nevertheless, a rapid degradation of a bone scaffold could lead to both high cytotoxicity and deterioration of the implant's mechanical properties. Adding appropriate alloying elements is a way of optimizing the degradation rate. One of these elements is phosphorus, known as an essential element maintaining physiological homeostatic processes. Alloying with small amounts of phosphorus (max. 0.6 wt.\%) has been known to increase the stress corrosion, sintered density, and the strength of powder steels, which makes it beneficial to materials with high porosity.

Using a replica method, the aim of the present work is to manufacture iron and iron-phosphorus open-cell, sintered foam alloys as potentially biodegradable materials. To vary mechanical properties and the corrosion rate, two types of Fe$\mathrm{P}$ alloyed foams were prepared. One was manufactured from a phosphated carbonyl iron powder, and the other was manufactured from a mixture of carbonyl iron and $\mathrm{Fe}_{3} \mathrm{P}$. The foams were tested for their microstructure, porosity, degradability, and mechanical properties. The manufactured scaffolds seem to exhibit properties worthy of further development as the biodegradable scaffold material for bone repair.

\section{Materials and Methods}

2.1. Materials. Carbonyl iron powder (Figure 1(a)) supplied by BASF, Germany (purity $\geq 99.5 \%$ ) with spherically shaped particles (d50 value $3.8-5.3 \mu \mathrm{m}$ ) was used as the starting material for all experiments. Two different methods were employed to produce an iron-phosphorus alloyed material. In the first method, the carbonyl iron particles were coated with phosphate layers [23].

The phosphating was carried out by mixing iron powder into a phosphating solution (with acetone as a solvent and orthophosphoric acid as a phosphating active agent) at room temperature for $2 \mathrm{~h}$ in air. The powder was then dried at $60^{\circ} \mathrm{C}$ for 2 hours and then calcinated at $400^{\circ} \mathrm{C}$ for $3 \mathrm{~h}$ in air.

The phosphated powder particles are shown in Figure 1(b). The phosphorus content in the phosphated powder was determined spectrophotometrically using UV-VIS Spectrophotometer (Shimadzu Japan).

In the second method, commercial $\mathrm{Fe}_{3} \mathrm{P}$, (purity $\geq 99.5 \%$ ), supplied by Alfa Aesar, was admixed into carbonyl iron. The powder mixture was homogenized in Turbula mixer for $30 \mathrm{~min}$. The total phosphorus content was $0.5 \mathrm{wt}$.\% in both cases.

2.2. Foam Preparation. Iron and iron-alloyed foams with interconnected structures were fabricated using a polymer sponge replica technique with polyurethane (PU) foam BULPREN S, supplied by POLY Slovakia (cell size 50$65 \mathrm{PPI}$ ) to serve as a sacrificial structure. The slurry for the foam fabrication was prepared by dissolving polyvinyl alcohol (PVA) in water. Subsequently, metallic powders were dispersed in the solution under constant stirring. 


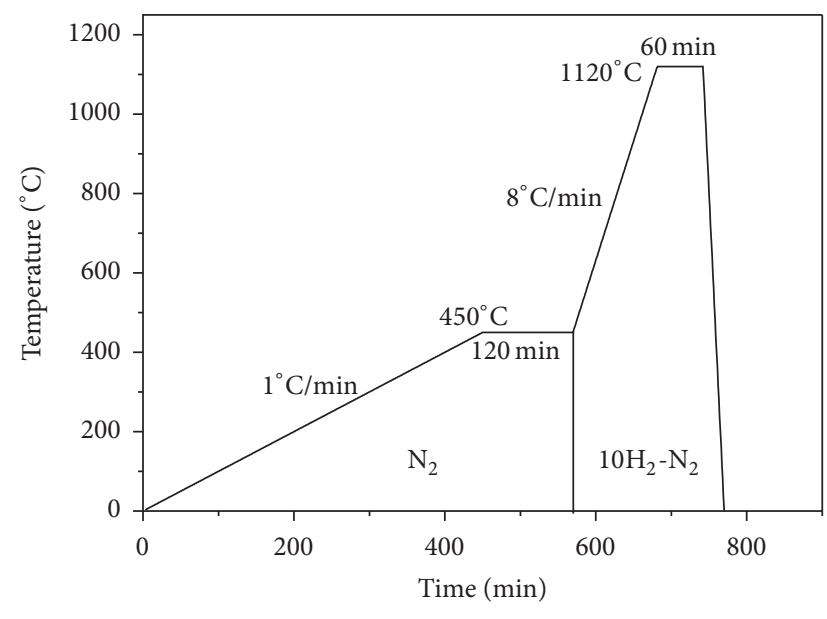

Figure 2: Scheme of the used heat treatment.

The infiltration of sponge with slurry for $3 \mathrm{~min}$ was repeated twice; the excess suspension was removed by rolling. The specimens were dried at room temperature and then subjected to a two-step heat procedure in the tube furnace CARBOLITE. Firstly, the specimens were annealed at $450^{\circ} \mathrm{C}$ for $2 \mathrm{~h}$ in a $\mathrm{N}_{2}$ atmosphere to decompose organic material. Secondly, the debinded metal structures were sintered at $1120^{\circ} \mathrm{C}$ for $1 \mathrm{~h}$ in an atmosphere of $10 \% \mathrm{H}_{2}-90 \% \mathrm{~N}_{2}$. Figure 2 provides a detailed and schematic description of the heat treatment used in the foam fabrication.

\subsection{Characterization of Materials}

2.3.1. Microstructure and Surface Morphology. The surface morphology of the uncoated and coated powder particles was observed by CrossBeam system AURIGA Compact (ZEISS). The microstructure and the surface morphology of the manufactured metallic foams were observed by a light microscope (Olympus GX7) and a scanning electron microscope (Jeol JSM 7000F, Japan, equipped with INCA EDX analyzer).

2.3.2. Determination of Density and Porosity. The sintered density was calculated by the Archimedes principle (DIN ISO3369). To avoid a penetration of open pores, the samples were wrapped in Parafilm and then weighed in air and water. The density was calculated according to

$$
\rho=\frac{m_{1}}{\left(m_{1 P}-m_{2 P}\right) / \rho_{W}-\left(m_{1 P}-m_{1}\right) / \rho_{P}},
$$

where $m_{1}[\mathrm{~g}]$ is the weight of the dried specimens before wrapping in Parafilm, $m_{1 P}[\mathrm{~g}]$ is the weight of the wrapped specimens weighed in air, $m_{2 P}[\mathrm{~g}]$ is the weight of the wrapped specimens weighed in water, $\rho_{W}\left[\mathrm{~g} \cdot \mathrm{cm}^{-3}\right]$ stands for the water density at room temperature $\left[\mathrm{g} \cdot \mathrm{cm}^{-3}\right]$, and $\rho_{P}$ $\left[\mathrm{g} \cdot \mathrm{cm}^{-3}\right]$ stands for the Parafilm density $\left[\mathrm{g} \cdot \mathrm{cm}^{-3}\right]$.

In order to determine the total porosity, the specimens were impregnated with benzyl alcohol in a vacuum and then weighted in air and in water again.
The volume $P_{T}$ of the total porosity was calculated according to

$$
P_{T}=\left[1-\frac{m_{1}}{\left(m_{2}-m_{3}\right) \cdot \gamma}\right] \cdot 100,
$$

where $m_{1}$ [g] stands for the weight of the dried specimens before saturation, $m_{2}[\mathrm{~g}]$ is the weight of the specimens saturated with benzyl alcohol, $m_{3}[\mathrm{~g}]$ is the weight of the saturated specimens weighed in water, and $\gamma\left[\mathrm{g} \cdot \mathrm{cm}^{-3}\right]$ represents the theoretical densities of metal.

The open porosity $P_{\mathrm{O}}$ was estimated according to

$$
P_{\mathrm{O}}=\frac{m_{2}-m_{1}}{\gamma_{B} \cdot\left(m_{2}-m_{3}\right)} \cdot 100 \%
$$

where $\gamma_{B}\left[\mathrm{~g} \cdot \mathrm{cm}^{-3}\right]$ stands for the density of benzyl alcohol. The closed porosity $P_{C}$ was calculated as the difference between the total and open porosity according to

$$
P_{\mathrm{C}}=P_{T}-P_{\mathrm{O}}
$$

2.3.3. Electrochemical Measurement. The degradation behaviour was studied by potentiodynamic polarization using the potentiostat PARSTAT 4000 (Princeton Applied Research, USA). The electrochemical tests were carried out at a constant temperature of $37 \pm 1^{\circ} \mathrm{C}$ in a glass beaker containing $150 \mathrm{~mL}$ of Hank's solution, in a simulated body liquid electrolyte with a $\mathrm{pH}$ value of 7.4 , or in a physiological saline solution $(0.9 \%$ $\mathrm{NaCl}$ ) with a $\mathrm{pH}$ of 5.9 , which represents a more aggressive environment.

The composition of the used Hank solution was as follows: $8 \mathrm{NaCl}, 0.4 \mathrm{KCl}, 0.14 \mathrm{CaCl}_{2}, 0.06 \mathrm{MgSO}_{4} \cdot 7 \mathrm{H}_{2} \mathrm{O}$, $0.06 \mathrm{NaH}_{2} \mathrm{PO}_{4} \cdot 2 \mathrm{H}_{2} \mathrm{O}, 0.35 \mathrm{NaHCO}_{3}, 1.00$ glucose, and $0.60 \mathrm{KH}_{2} \mathrm{PO}_{4}$ and $0.10 \mathrm{MgCl}_{2} \cdot 6 \mathrm{H}_{2} \mathrm{O}$ (in $\mathrm{g} / \mathrm{L}$ ). We used a standard three-electrode system with a platinum foil as a counterelectrode, a saturated calomel electrode as a reference electrode, and the foam sample as a working electrode, Figure 3(a).

The working electrode with an exposed area of $1.5 \mathrm{~cm}^{2}$ was first immersed in the electrolyte for $120 \mathrm{~min}$ to measure its Open Circuit Potential (OCP). Figure 3(b) shows the method of attaching specimens. The potentiodynamic polarization was carried out by varying the applied potential from $-250 \mathrm{mV}$ to $+250 \mathrm{mV}$ relative to OCP at a scanning rate of $0.1666 \mathrm{mV} / \mathrm{s}$. We tested three specimens of each type. The corrosion rate and the corrosion current densities were determined using a simplified Tafel extrapolation method.

2.3.4. Mechanical Properties. We investigated the mechanical behaviour of the manufactured foams under uniaxial compression. The tests were carried out on three samples $(15 \times 12$ $\times 5 \mathrm{~mm}$ ) of each foam type, using a universal testing mashing (TiraTest 2300, Germany), at head speed of $0.001 \mathrm{~mm} / \mathrm{s}$ and a load of $1 \mathrm{kN}$. ASTM D1621-00 and ISO 844 standard were used to determine the yield strength and the modulus of elasticity. The modulus of elasticity was measured as the slope of the stress-strain curves in the elastic deformation region. 


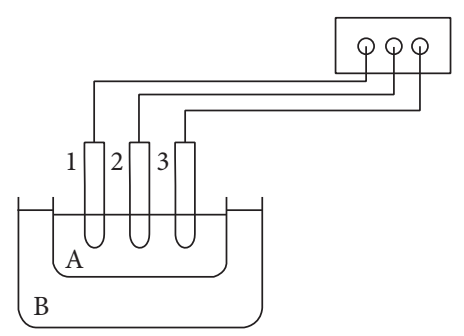

1: Reference electrode

2: Working electrode

3: Counterelectrode

A: Electrolyte $\left(37 \pm 1^{\circ} \mathrm{C}\right)$

B: Water bath

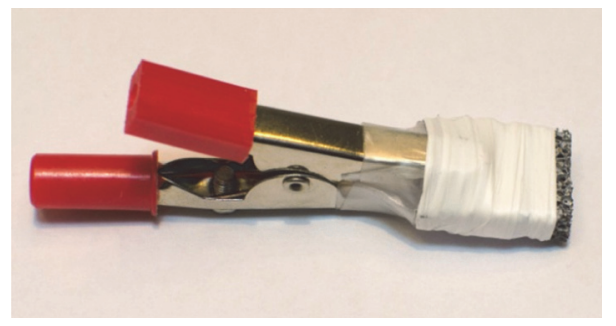

(a)

(b)

Figure 3: (a) The scheme of the electrochemical test. (b) The method of sample attachment.

The offset yield strengths were determined as the stress values at $0.2 \%$ plastic strain.

The hardness of the metallic skeleton material was measured on metallographic cross sections of the foams. The hardness of the solid ligaments was measured with a microhardness tester LECO LM-700AT. For each sample, 50 indents were performed; the load was $10 \mathrm{~g}$ and the dwell time was $10 \mathrm{~s}$. The indents were made with an indent separation of $40 \mu \mathrm{m}$ in five distant places on the samples' surface. If the Vickers indenter is used and the indent's main diagonal is $d$, then its depth is $d / 7$ [24]. In the present experiment, the maximum value of the diagonal reached around $20 \mu \mathrm{m}$ with the indentation depth of app. $2.9 \mu \mathrm{m}$. One can see that the depth of the indentation is very low compared to the thickness of the foam skeleton walls.

\section{Results and Discussion}

3.1. Characteristics of Metallic Foams. Figure 4 shows the iron and iron-based foams produced by a replica method, using slurry infiltrated into a polyurethane sponge. The pure iron foam is labelled as Fe, the foam from a carbonyl phosphated powder is labelled as $\mathrm{Fe}-\mathrm{P}(\mathrm{I})$, and the one prepared from a mixture of $\mathrm{Fe}^{-} \mathrm{Fe}_{3} \mathrm{P}$ is labelled as $\mathrm{Fe}-\mathrm{P}(\mathrm{II})$.

As can be seen, this method enables preparing metallic foams with an open, three-dimensional, interconnected macroporous network, which is one of the most essential requirements for tissue ingrowth. An advantage of the replica method is the possibility of manufacturing a scaffold with a required pore size matching the selected template, because the final structure of all prepared foams is close to the desired template structure. Similar morphological structures of foams have also been reported by other researchers using a replica method [22].

The visual inspection of the foams revealed a shrinkage of the Fe-P(I) foam as compared to the Fe and Fe-P(II) foams. The visible shrinkage of about $10 \%$ was caused by the presence of a liquid phase created by the interaction of the $\mathrm{Fe}_{2} \mathrm{O}_{3}-\mathrm{P}_{2} \mathrm{O}_{5}$ system that assisted the sintering of the phosphated carbonyl iron at $1120^{\circ} \mathrm{C}$ [25].
Porosity, pore size, and pore interconnectivity are key factors that significantly affect the mechanical properties and the biological performance of a scaffold, such as bone ingrowth and the transportation of cells and nutrients [26]. As proposed by Wen et al. [3], the pore size of $100-500 \mu \mathrm{m}$ is sufficient to enable the ingrowth of vascular tissues. However, large pores are an advantage in case of larger implants that require a deeper penetration. The pore size of the Fe and Fe$\mathrm{P}$ (II) foams ranged between 300 and $800 \mu \mathrm{m}$, and the pores of the Fe-P(I) foam were smaller, ranging between 250 and $700 \mu \mathrm{m}$.

Another important factor related to the fixation ability of scaffolds is their specific surface area [26]. Small pores are believed to provide a larger surface area and thus more space for the bone tissue ingrowth. As Figure 5 shows, the walls of the macropores have a relatively rough surface, with a large amount of micropores. These can be divided into two groups: micropores sized over $10 \mu \mathrm{m}$ are created by the release of gases during the decomposition of a polyurethane sponge. The rounded micropores sized under $5 \mu \mathrm{m}$ are created by sintering during the foam manufacturing. The BET method showed that the specific surface areas of the Fe, $\mathrm{Fe}-\mathrm{P}(\mathrm{I})$, and Fe-P(II) foams were $0.39 \mathrm{~m}^{2} / \mathrm{g}, 0.35 \mathrm{~m}^{2} / \mathrm{g}$, and $0.37 \mathrm{~m}^{2} / \mathrm{g}$, respectively. Figure 5 shows the cross section of the foams' pore walls. An image analysis determined a following decrease in the porosity of the macropores' walls: $\mathrm{Fe}>\mathrm{Fe}$ (II) $>\mathrm{Fe}(\mathrm{I})$, reaching $21 \%, 15 \%$, and $8 \%$, respectively.

The average size of micropores was $14.5 \mu \mathrm{m}^{2}$ for the $\mathrm{Fe}$ foam and $5.3 \mu \mathrm{m}^{2}$ and $12.3 \mu \mathrm{m}^{2}$ for the Fe-P(I) and the Fe$\mathrm{P}$ (II) foams, respectively. Surface areas this large provide more space for the scaffold/bone tissue interface, which can accelerate the bone reparation. Table 1 presents the average values for the density, total porosity level, and the open/closed porosity of the prepared iron-based foams. Values were obtained by measuring five samples of each foam type.

The densities of the prepared foams ranged between 0.73 and $0.94 \mathrm{~g} \cdot \mathrm{cm}^{-3}$. Slightly higher density values obtained for 

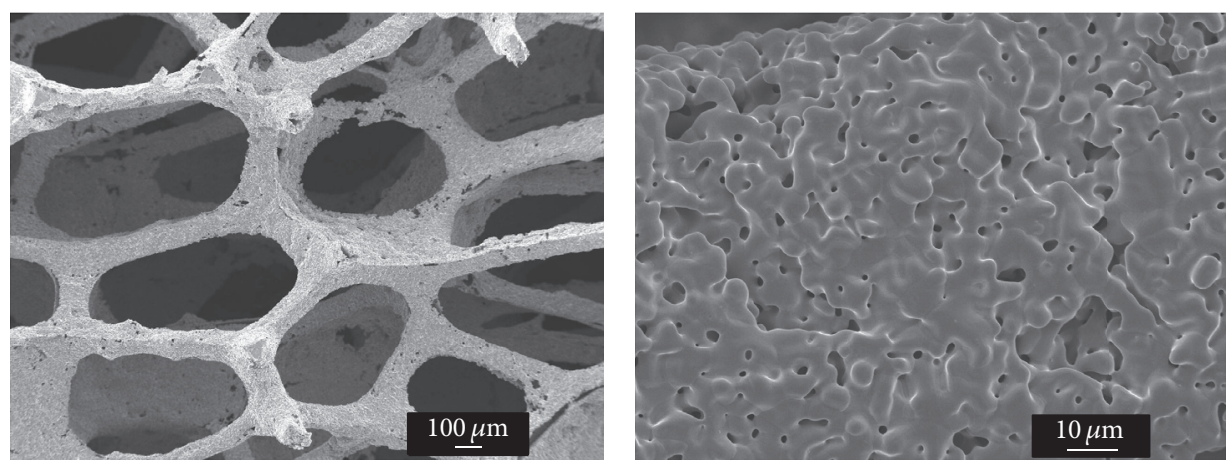

(a)
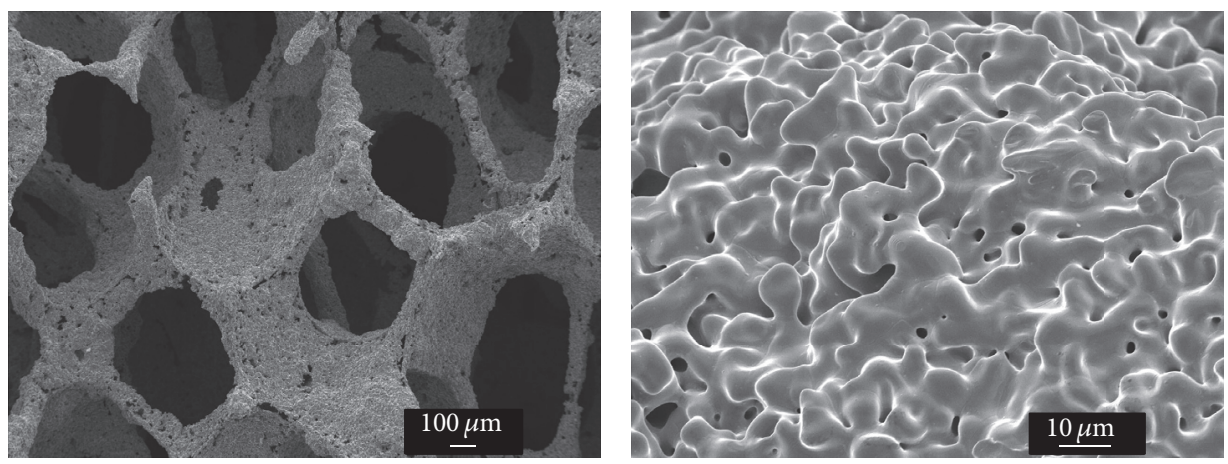

(b)
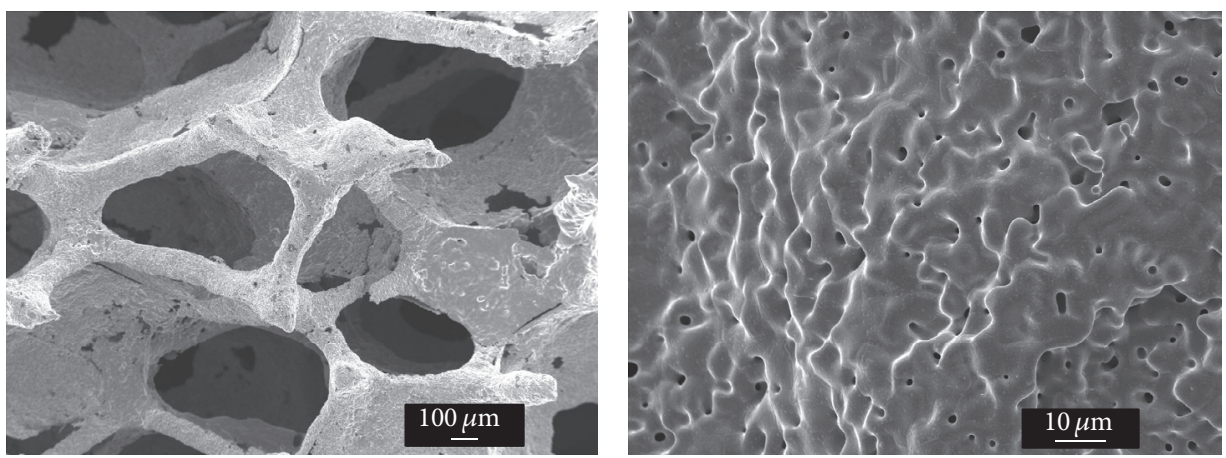

(c)

FIgURE 4: SEM image of the foams prepared by a replica method: (a) pure Fe, (b) Fe-P(I), and (c) Fe-P(II).

phosphorus alloyed foams may have a positive effect on the mechanical properties. The total porosities of the manufactured $\mathrm{Fe}, \mathrm{Fe}-\mathrm{P}(\mathrm{I})$, and $\mathrm{Fe}-\mathrm{P}(\mathrm{II})$ foams ranged between 88 and $89 \%$. All samples obviously contained both close and open pores. The open porosity of the manufactured foams, constituted by both macropores and micropores, accounted for $81-84 \%$ of the total volume. In addition to open porosity, there is a lower percentage of closed porosity reaching about $5-7 \%$. Pores may get partially closed due to the formation of liquid films bridging the cell walls [27]. A higher occurrence of closed pores was observed in the Fe-P(I) foams, which may have to do with the shrinkage of samples during sintering.

Using a replica method, foams with a structure similar to that of a cancellous bone [28] were prepared. Not only did the network of interconnected macropores allow for tissue
TABLE 1: Density and total and open porosities of iron and ironbased foams.

\begin{tabular}{lcccc}
\hline Material & $\begin{array}{c}\text { Density } \\
{\left[\mathrm{g} \cdot \mathrm{cm}^{-3}\right]}\end{array}$ & $\begin{array}{c}\text { Total } \\
\text { porosity } \\
{[\%]}\end{array}$ & $\begin{array}{c}\text { Open porosity } \\
{[\%]}\end{array}$ & $\begin{array}{c}\text { Closed } \\
\text { porosity } \\
{[\%]}\end{array}$ \\
\hline Fe & 0.73 & 89 & 84 & 5 \\
Fe-P(I) & 0.94 & 88 & 81 & 7 \\
Fe-P(II) & 0.84 & 89 & 84 & 5 \\
\hline
\end{tabular}

ingrowth, but it also proved suitable for the transportation of nutrients and metabolic waste; micropores may enhance osteoconductivity. 


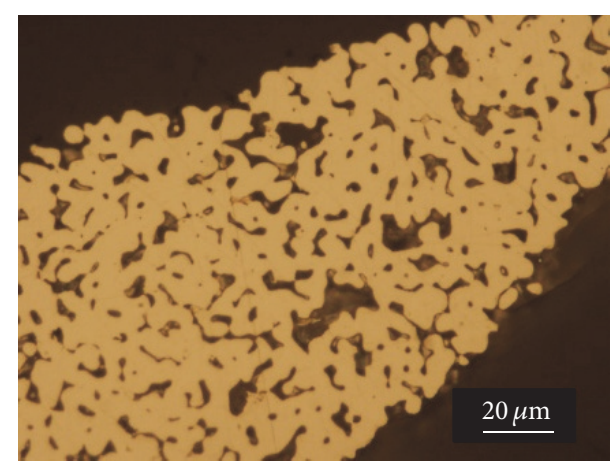

(a)

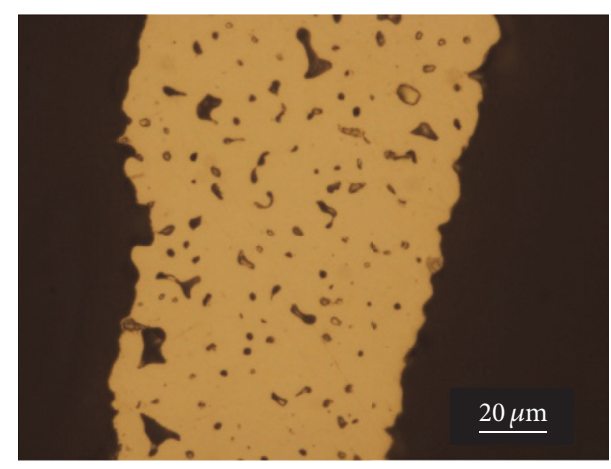

(b)

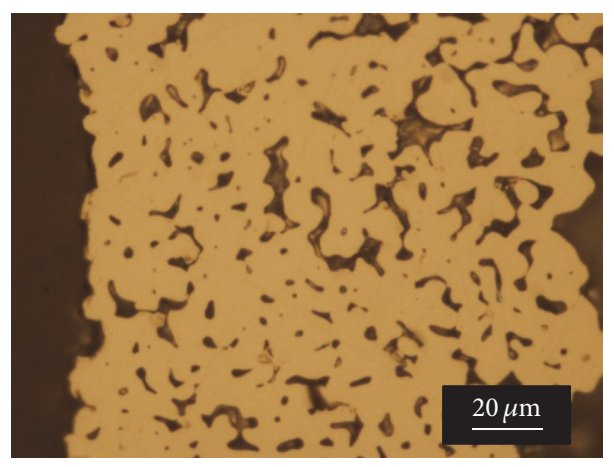

(c)

Figure 5: Metallographic cross section of the pore walls of the manufactured foams: (a) Fe, (b) Fe-P(I), and (c) Fe-P(II) foam.

3.2. Corrosion Behaviour. As Alsberg et al. [29] reported, scaffold degradation represents a critical parameter for the bone tissue regeneration, because appropriate scaffold degradability provides the space for the matrix deposition and tissue growth, which may ultimately improve the quantity and quality of the regenerated bone.

In the present study, we studied the degradation of the manufactured iron and iron-based foams by anodic polarization at $37 \pm 1^{\circ} \mathrm{C}$ in a simulated body solution. The corrosion behaviour in a neutral environment was studied in Hank's solution with a $\mathrm{pH}$ of 7.4. A more aggressive environment was simulated by a physiological saline solution $(0.9 \% \mathrm{NaCl})$ with a $\mathrm{pH}$ of 5.9 .

Figure 6 shows typical curves obtained by potentiodynamic polarization after stabilizing the specimens for $120 \mathrm{~min}$ in different simulated body solutions recorded at a scan rate of $0.1666 \mathrm{mV} / \mathrm{s}$. The corrosion potential $\left(E_{\text {corr }}\right)$ and the corrosion current density $\left(i_{\text {corr }}\right)$ were calculated from the intersection of the anodic and cathodic Tafel lines extrapolation. The average electrochemical parameters and the corrosion rate (CR) are listed in Table 2.

The corrosion potential of the Fe-P(I) foams tested in Hank's solution was shifted to higher values as compared to the corrosion potential of the Fe and Fe(II) foams. This more noble corrosion potential indicates a lower corrosion susceptibility of Fe-P(I) foams.

It is a generally known fact that steels alloyed with small amounts of phosphorus exhibit an increased corrosion resistance. In addition, inorganic phosphate compounds are
TABLE 2: The average values for the corrosion potentials $\left(E_{\text {corr }}\right)$, corrosion current densities $\left(i_{\text {corr }}\right)$, and the corrosion rate (CR) obtained from the potentiodynamic polarization curves in Hank's solution ( $\mathrm{pH} \mathrm{7.4)} \mathrm{and} 0.9 \% \mathrm{NaCl}\left(\mathrm{pH} \mathrm{5.9)}\right.$ at $37 \pm 1^{\circ} \mathrm{C}$.

\begin{tabular}{lcccccc}
\hline \multirow{2}{*}{ Material } & \multicolumn{2}{c}{ ECORR $[\mathrm{mV}]$} & \multicolumn{2}{c}{$i_{\text {corr }}\left[\mu \mathrm{A} / \mathrm{cm}^{2}\right]$} & \multicolumn{2}{c}{ CR $[\mathrm{mm} / \mathrm{y}]$} \\
& Hank's & NaCl & Hank's & $\mathrm{NaCl}$ & Hank's & $\mathrm{NaCl}$ \\
\hline Fe & -705 & -781 & 87.8 & 232.6 & 0.44 & 1.01 \\
Fe-P(I) & -596 & -774 & 70.5 & 97.3 & 0.27 & 0.57 \\
Fe-P(II) & -714 & -727 & 84.4 & 199.9 & 0.38 & 0.88 \\
\hline
\end{tabular}

known to work as corrosion inhibitors for iron and carbon steels in solutions with a near-neutral pH [30]. As Kabátová et al. [25] report for sintered microstructure of phosphate iron powder, the spherical $\alpha$-Fe phase and iron oxide phases are surrounded by a solidified liquid phase containing ferric phosphate compounds such as $\mathrm{FePO}_{4}, \mathrm{Fe}_{3} \mathrm{PO}_{7}$, and $\mathrm{Fe}_{4}\left(\mathrm{P}_{2} \mathrm{O}_{7}\right)$. Iron phosphates react with iron ions to form a precipitate which inhibits corrosion. In accordance with this, the corrosion current densities $\left(i_{\text {coor }}\right)$ and the corrosion rate of the manufactured foams increased in Hank's solution as follows: $\mathrm{Fe}-\mathrm{P}(\mathrm{I})<\mathrm{Fe}-\mathrm{P}(\mathrm{II})<\mathrm{Fe}$, Table 2 . The corrosion rates reported for porous iron materials are higher than those for the nonporous ones [8]. This could be related to higher roughness, greater surface area, and the penetrable structure of the porous materials.

In the saline solution, the corrosion potential of all tested foams was shifted to lower values. Contrasting with Hank's 


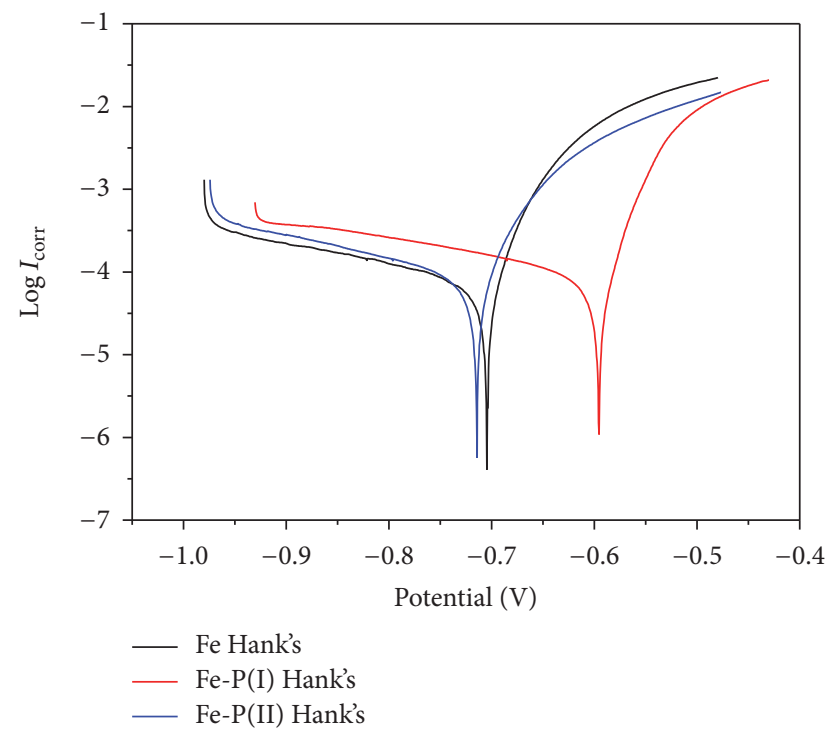

(a)

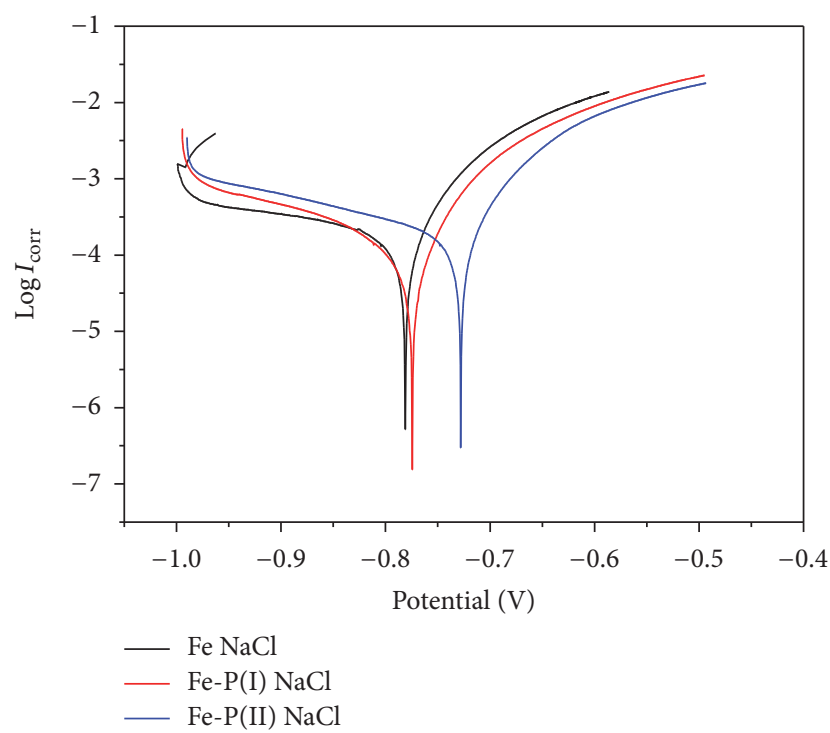

(b)

Figure 6: Potentiodynamic polarization curves of the manufactured foams in (a) Hank's solution, $\mathrm{pH} 7,4$, and (b) $0.9 \% \mathrm{NaCl}$, pH 5.9, at $37 \pm$ $1^{\circ} \mathrm{C}$ at a scan rate of $0.1666 \mathrm{mV} / \mathrm{s}$.

solution, the highest values of corrosion potential in the saline solution were attested for the Fe-P(II) foam. Despite this noble potential, the corrosion rate of the Fe-P(II) foams was higher than that of the Fe-P(I) foams.

Ratio-wise, we arrived at attested similar values for the corrosion rate and the corrosion current density in both solutions, except that all corrosion rates attested in the saline solution were twice as high as in Hank's solution. As reported by Oriňáková et al. [18], the amount of corrosion products found on the surface of the specimens in a saline solution is higher than in Hank's solution. The lower corrosion rate attested for Hank's solution might be caused by a different chemical composition of the corrosion products formed during the corrosion test. The corrosion layer formed in Hank's solution is more protective than the one formed in a saline solution, because it also contains $\mathrm{Ca}$ and $\mathrm{P}$ precipitates [31], the presence of which can inhibit the corrosion process. It generally held that the presence of phosphorus in the sintered iron foams inhibited the corrosion rate in both tested solutions. A higher corrosion resistance was observed in the foams prepared from the phosphated carbonyl iron powder.

3.3. Mechanical Properties. When under compression, opencell foams respond to the applied stress universally, no matter what material the foam is made of. The stress-strain curve generally consists of three distinct regions: (1) a quasi-elastic linear increase in stress for small compressive strains, (2) a "plateau" region characterized by no or very small slope of the stress-strain curve, and (3) a region of densification with rapidly increasing stress $[32,33]$.

Foam's initial linear response to an increase in stress (i.e., the elastic deformation) is controlled by bending and stretching of the cell edges or cell faces. The plateau has to do with a collapse of cells. This is due to plastic yielding or brittle crushing of cell edges (faces), all depending on the properties of the material that the foam is made of. The stress-strain curve in the plateau region is quite smooth for a ductile solid skeleton but tends to be rather jagged for a brittle skeleton. The slope of the plateau region depends on whether the cells (pores) are open or closed. Open-cell foams continue to collapse at an almost constant load, thus providing a long flat plateau. In case of closed-cell foams, the deformation of cell faces and the compression of gas confined in the cells prevent further deformation. Therefore, it takes a continuous increase in compressive stress for a deformation to proceed. Nevertheless, it holds for all foams that the lower the foam density, the longer the plateau region $[32,33]$.

When densified, the cell edges and faces touch each other. Consequently, with all pores compressed, further strain means compression of the solid material itself, providing the final region with rapidly increasing stress.

Figure 7 shows typical compressive stress-strain curves recorded for the $\mathrm{Fe}, \mathrm{Fe}-\mathrm{P}(\mathrm{I})$, and the $\mathrm{Fe}-\mathrm{P}(\mathrm{II})$ foams. In all cases, the initial quasi-elastic deformation is followed by a plastic deformation. In addition, the figure shows that all samples exhibited regular and smooth behaviour within the plateau region, which is a typical feature of ductile metallic foams.

The elastic deformation portions of all specimens are in a range of strains from 3 to $10 \%$. These small ranges imply that all foam samples exhibited low elastic deformation at low compressive stress before undergoing large plastic deformation. The yield stress was determined as a measure of stress required to produce a plastic deformation of $0.2 \%$. It can be seen that the addition of phosphorus generally increased the yield strength of both Fe-P(I) and Fe-P(II) foams as compared to the Fe foam samples. The compressive 


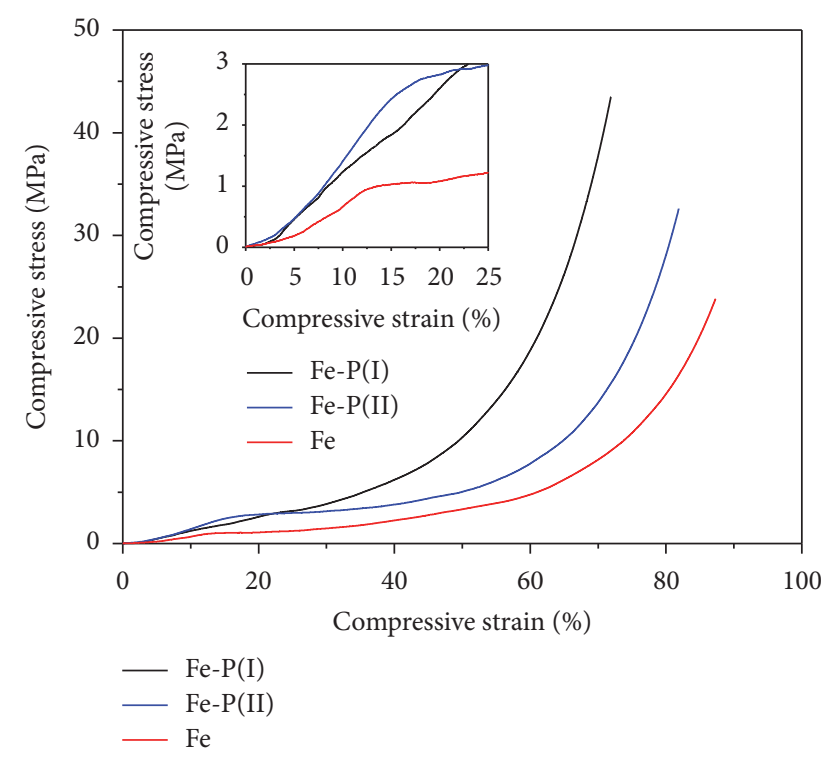

FIgURE 7: Compressive stress-strain curves for the Fe, Fe-P(I), and Fe-P(II) foams.

TABLE 3: Mechanical properties of the manufactured Fe, Fe-P(I), and Fe-P(II) foams.

\begin{tabular}{lccc}
\hline Material & $\begin{array}{c}\text { Yield strength [MPa] } \\
\text { Rp 0.2 [MPa] }\end{array}$ & $\begin{array}{c}\text { Elastic modulus } \\
{[\mathrm{MPa}]}\end{array}$ & $\begin{array}{c}\text { Hardness HV } \\
0.01\end{array}$ \\
\hline Fe & $1.1 \pm 0.19$ & $15.3 \pm 2.79$ & $68 \pm 13.0$ \\
Fe-P(I) & $1.2 \pm 0.38$ & $15.9 \pm 2.91$ & $133 \pm 35.5$ \\
Fe-P(II) & $2.1 \pm 0.30$ & $22.4 \pm 6.80$ & $278 \pm 80.7$ \\
\hline
\end{tabular}

strength of all manufactured foams ranges within the scope of cancellous bone, $0.2-10 \mathrm{MPa}[34,35]$.

The differences in behaviour of the Fe, Fe-P(I), and Fe$\mathrm{P}(\mathrm{II})$ samples were observed in the plateau region and at the densification stage. The plateau regions of the Fe and Fe-P(II) samples were relatively longer than the plateau region of the Fe-P(I) sample.

The steepest stress-strain curve in the "plateau" region was recorded for the Fe-P(I) foam. This has most likely to do with the fact that the Fe-P(I) foam exhibited the highest closed-to-total porosity ratio, Table 1 . The Fe-P(II) foams had the highest yield strength. This is in accord with the highest hardness value obtained for the solid skeleton walls of the Fe-P(II) foams, Table 3. Hardness of skeleton material is proportionate to its yield strength. Since the porosities of the investigated foams are nearly equal, the differences in their properties are mainly determined by the differences in their respective solid skeleton properties. The high hardness of the Fe-P(II) matrix material probably resulted from the presence of a liquid phase during sintering.

The lowest deformation at which the densification phase started was attested for the Fe-P(I) samples. This might be due to the fact that its pores were the smallest of all samples.

\section{Conclusion}

Iron-based cellular materials with an open interconnected structure and porosity up to $89 \%$ were successfully fabricated by a replica method. This production route generates a cell structure similar to that of cancellous bone. The samples with added phosphorus were manufactured in order to improve the mechanical properties. Two different types of Fe-P foams with 0.5 wt.\% of phosphorus were prepared, Fe-P(I) from a phosphated carbonyl iron powder and $\mathrm{Fe}-\mathrm{P}(\mathrm{II})$ from a mixture of carbonyl iron and $\mathrm{Fe}_{3} \mathrm{P}$. Phosphorus proved to be a suitable alloying element for the foam manufacture due to its beneficial effect on the sintered density which significantly enhanced the mechanical strength. An electrochemical study of the corrosion properties showed that the Fe-P foams inhibited corrosion. A lower corrosion rate was observed for the Fe-P foam prepared from a phosphated carbonyl iron powder. Iron and iron-phosphorus alloyed foams prepared by a powder metallurgical replication route seem to be suitable candidates for new biodegradable bone grafts capable of bearing high loads.

Nevertheless, further research of the biocorrosion rate regulation and in vitro investigations of the biocompatibility of such materials will be necessary.

\section{Competing Interests}

The authors declare that they have no competing interests.

\section{Acknowledgments}

This work was supported by Project APVV-0677-11 of the Slovak Research and Development Agency and Project VEGA 2/0100/15 of the Slovak Scientific Grant Agency.

\section{References}

[1] S. Bose, S. Vahabzadeh, and A. Bandyopadhyay, "Bone tissue engineering using 3D printing," Materials Today, vol. 16, no. 12, pp. 496-504, 2013.

[2] M. Long and H. J. Rack, "Titanium alloys in total joint replacement-a materials science perspective," Biomaterials, vol. 19, no. 18, pp. 1621-1639, 1998.

[3] C. E. Wen, M. Mabuchi, Y. Yamada, K. Shimojima, Y. Chino, and T. Asahina, "Processing of biocompatible porous Ti and Mg," Scripta Materialia, vol. 45, no. 10, pp. 1147-1153, 2001.

[4] K. Kato, A. Yamamoto, S. Ochiai et al., "Cytocompatibility and mechanical properties of novel porous 316 L stainless steel," Materials Science and Engineering C, vol. 33, no. 5, pp. 27362743, 2013.

[5] A. H. Yusop, A. A. Bakir, N. A. Shaharom, M. R. Abdul Kadir, and H. Hermawan, "Porous biodegradable metals for hard tissue scaffolds: a review," International Journal of Biomaterials, vol. 2012, Article ID 641430, 10 pages, 2012.

[6] X. N. Gu, W. R. Zhou, Y. F. Zheng, Y. Liu, and Y. X. Li, "Degradation and cytotoxicity of lotus-type porous pure magnesium as potential tissue engineering scaffold material," Materials Letters, vol. 64, no. 17, pp. 1871-1874, 2010.

[7] B. Wegener, B. Sievers, S. Utzschneider et al., "Microstructure, cytotoxicity and corrosion of powder-metallurgical iron alloys 
for biodegradable bone replacement materials," Materials Science and Engineering B: Solid-State Materials for Advanced Technology, vol. 176, no. 20, pp. 1789-1796, 2011.

[8] M. Moravej and D. Mantovani, "Biodegradable metals for cardiovascular stent application: interests and new opportunities," International Journal of Molecular Sciences, vol. 12, no. 7, pp. 4250-4270, 2011.

[9] G. Song and S. Song, "A possible biodegradable magnesium implant material," Advanced Engineering Materials, vol. 9, no. 4, pp. 298-302, 2007.

[10] M. Peuster, C. Hesse, T. Schloo, C. Fink, P. Beerbaum, and C. von Schnakenburg, "Long-term biocompatibility of a corrodible peripheral iron stent in the porcine descending aorta," Biomaterials, vol. 27, no. 28, pp. 4955-4962, 2006.

[11] M. Schinhammer, I. Gerber, A. C. Hänzi, and P. J. Uggowitzer, "On the cytocompatibility of biodegradable Fe-based alloys," Materials Science and Engineering C, vol. 33, no. 2, pp. 782-789, 2013.

[12] B. Liu and Y. F. Zheng, "Effects of alloying elements (Mn, Co, Al, W, Sn, B, C and S) on biodegradability and in vitro biocompatibility of pure iron," Acta Biomaterialia, vol. 7, no. 3, pp. 1407-1420, 2011.

[13] M. Moravej, F. Prima, M. Fiset, and D. Mantovani, "Electroformed iron as new biomaterial for degradable stents: development process and structure-properties relationship," Acta Biomaterialia, vol. 6, no. 5, pp. 1726-1735, 2010.

[14] S. Zhu, N. Huang, L. Xu et al., "Biocompatibility of Fe-O films synthesized by plasma immersion ion implantation and deposition," Surface and Coatings Technology, vol. 203, no. 1011, pp. 1523-1529, 2009.

[15] L. D. Zardiackas, D. E. Parsell, L. D. Dillon, D. W. Mitchell, L. A. Nunnery, and R. Poggie, "Structure, metallurgy, and mechanical properties of a porous tantalum foam," Journal of Biomedical Materials Research, vol. 58, no. 2, pp. 180-187, 2001.

[16] A. J. T. Clemow, A. M. Weinstein, J. J. Klawitter, J. Koeneman, and J. Anderson, "Interface mechanics of porous titanium implants," Journal of Biomedical Materials Research, vol. 15, no. 1, pp. 73-82, 1981.

[17] A. Oriňák, R. Oriňáková, Z. O. Králová et al., "Sintered metallic foams for biodegradable bone replacement materials," Journal of Porous Materials, vol. 21, no. 2, pp. 131-140, 2014.

[18] R. Oriňáková, A. Oriňák, L. M. Bučková et al., "Iron based degradable foam structures for potential orthopedic applications," International Journal of Electrochemical Science, vol. 8, no. 12, pp. 12451-12465, 2013.

[19] Z. Wen, L. Zhang, C. Chen, Y. Liu, C. Wu, and C. Dai, "A construction of novel iron-foam-based calcium phosphate/chitosan coating biodegradable scaffold material," Materials Science and Engineering C, vol. 33, no. 3, pp. 1022-1031, 2013.

[20] A. H. M. Yusop, N. M. Daud, H. Nur, M. R. A. Kadir, and H. Hermawan, "Controlling the degradation kinetics of porous iron by poly(lactic-co-glycolic acid) infiltration for use as temporary medical implants," Scientific Reports, vol. 5, Article ID 11194, 2015.

[21] N. M. Daud, N. B. Sing, A. H. Yusop, F. A. Abdul Majid, and H. Hermawan, "Degradation and in vitro cell-material interaction studies on hydroxyapatite-coated biodegradable porous iron for hard tissue scaffolds," Journal of Orthopaedic Translation, vol. 2, no. 4, pp. 177-184, 2014.

[22] J. He, F. L. He, D. W. Li, Y. L. Liu, and D. C. Yin, "A novel porous $\mathrm{Fe} / \mathrm{Fe}-\mathrm{W}$ alloy scaffold with a double-layer structured skeleton: preparation, in vitro degradability and biocompatibility," Colloids and Surfaces B: Biointerfaces, vol. 142, pp. 325-333, 2016.

[23] H. Bruncková, M. Kábatová, and E. Dudrová, “The effect of iron phosphate, alumina and silica coatings on the morphology of carbonyl iron particles," Surface and Interface Analysis, vol. 42, no. 1, pp. 13-20, 2010.

[24] S. K. Das and P. Sahoo, "Influence of process parameters on microhardness of electroless Ni-B coatings," Advances in Mechanical Engineering, vol. 2012, Article ID 703168, 11 pages, 2012.

[25] M. Kabátová, E. Dudrová, and H. Bruncková, “The effect of calcination on morphology of phosphate coating and microstructure of sintered iron phosphated powder," Surface and Interface Analysis, vol. 45, no. 7, pp. 1166-1173, 2013.

[26] X. Wang, S. Xu, S. Zhou et al., “Topological design and additive manufacturing of porous metals for bone scaffolds and orthopaedic implants: a review," Biomaterials, vol. 83, pp. 127141, 2016.

[27] A. Kennedy, "Porous metals and metal foams made from powders," in Powder Metallurgy, K. Kondoh, Ed., chapter 2, pp. 31-46, InTech, Rijeka, Croatia, 2012.

[28] D. P. Fyhrie and J. H. Kimura, "Cancellous bone biomechanics," Journal of Biomechanics, vol. 32, no. 11, pp. 1139-1148, 1999.

[29] E. Alsberg, H. J. Kong, Y. Hirano, M. K. Smith, A. Albeiruti, and D. J. Mooney, "Regulating bone formation via controlled scaffold degradation," Journal of Dental Research, vol. 82, no. 11, pp. 903-908, 2003.

[30] C. A. Borrás, R. Romagnoli, and R. O. Lezna, "In-situ spectroelectrochemistry (UV-visible and infrared) of anodic films on iron in neutral phosphate solutions," Electrochimica Acta, vol. 45, no. 11, pp. 1717-1725, 2000.

[31] J. Cheng and Y. F. Zheng, "In vitro study on newly designed biodegradable $\mathrm{Fe}-\mathrm{X}$ composites (X = W, CNT) prepared by spark plasma sintering," Journal of Biomedical Materials Research-Part B Applied Biomaterials, vol. 101, no. 4, pp. 485-497, 2013.

[32] M. F. Ashby, L. Gibson, and A. Evans, Metal Foams: A Design Guide, Butterworth-Hainemann, Oxford, UK, 2000.

[33] M. F. Ashby, “The properties of foams and lattices," Philosophical Transactions of the Royal Society of London A: Mathematical, Physical and Engineering Sciences, vol. 364, no. 1838, pp. 15-30, 2006.

[34] J. Teo, S. C. Wang, and S. H. Teoh, "Preliminary study on biomechanics of vertebroplasty: a computational fluid dynamics and solid mechanics combined approach," Spine, vol. 32, no. 12, pp. 1320-1328, 2007.

[35] C. V. Rahman, G. Kuhn, L. J. White et al., "PLGA/PEG-hydrogel composite scaffolds with controllable mechanical properties," Journal of Biomedical Materials Research-Part B Applied Biomaterials, vol. 101, no. 4, pp. 648-655, 2013. 

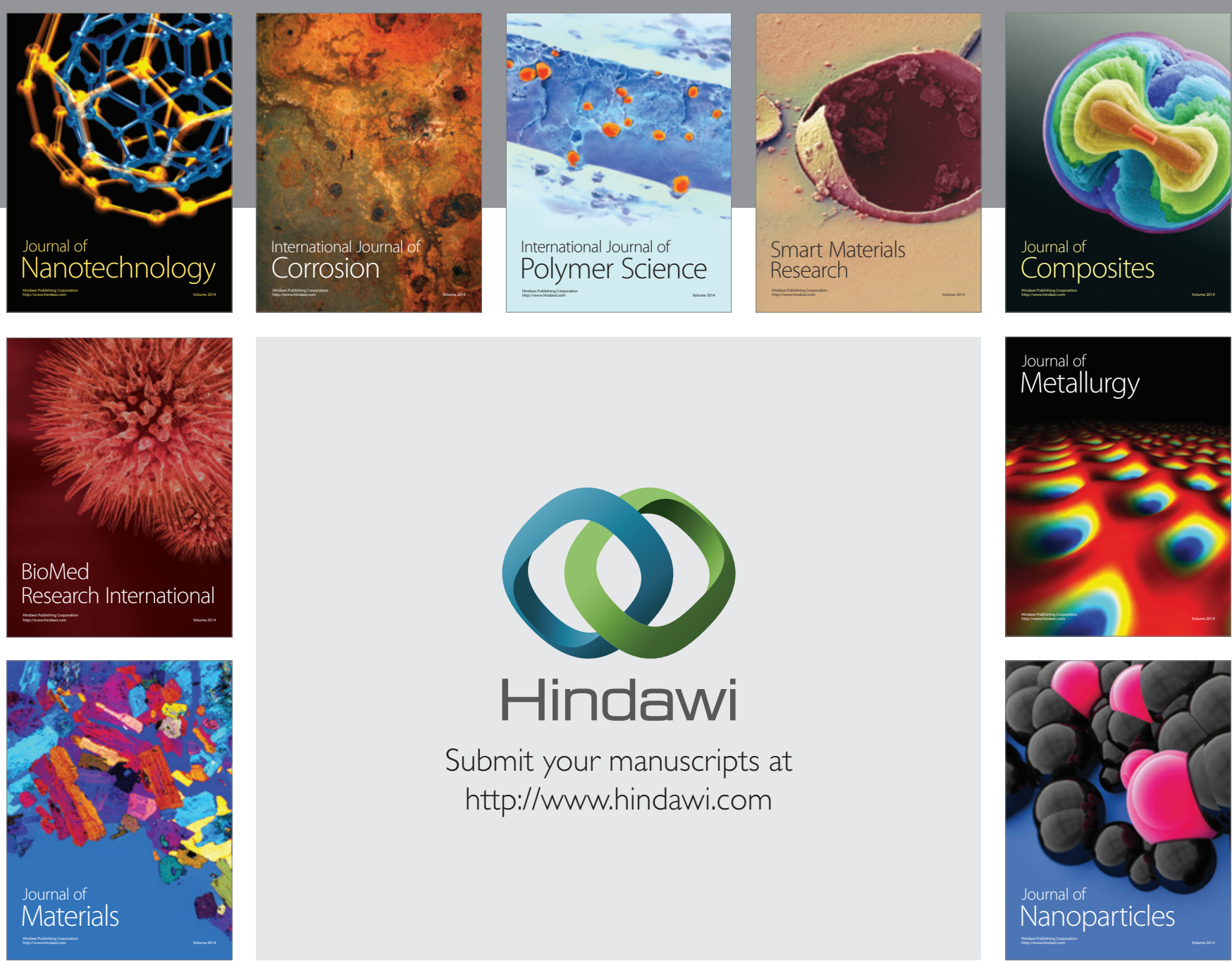

\section{Hindawi}

Submit your manuscripts at

http://www.hindawi.com

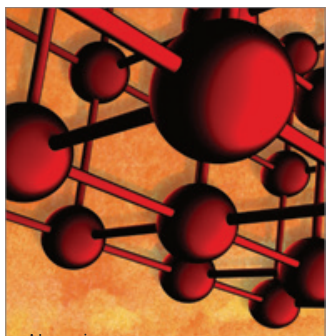

Materials Science and Engineering
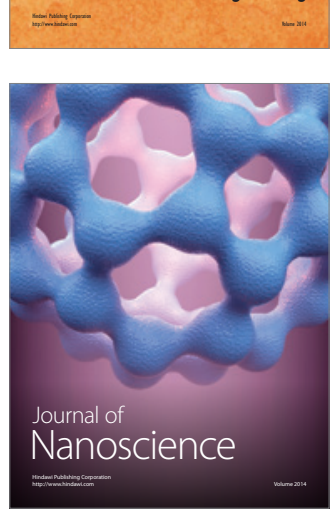
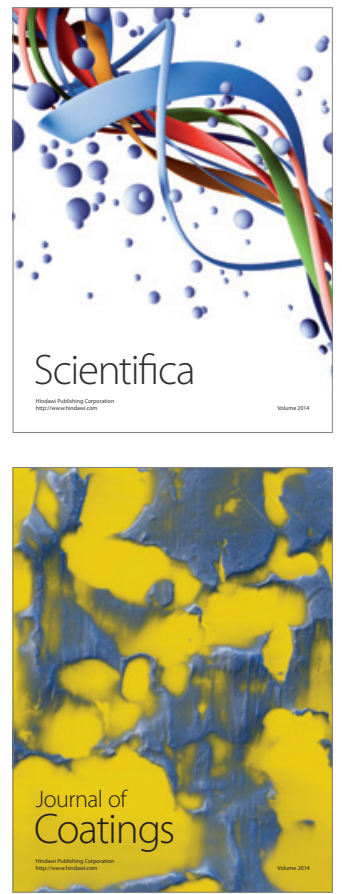
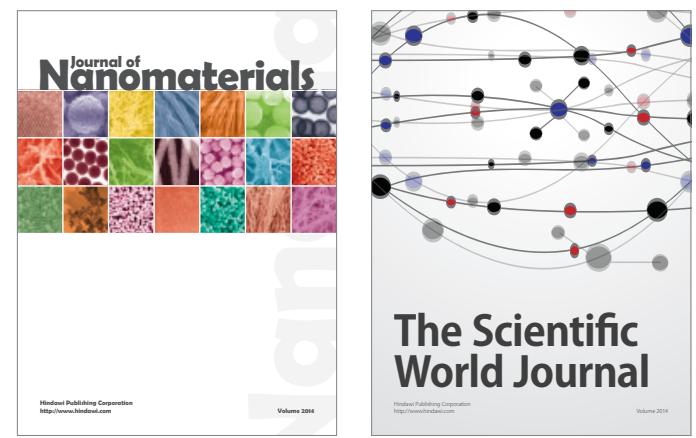

The Scientific World Journal
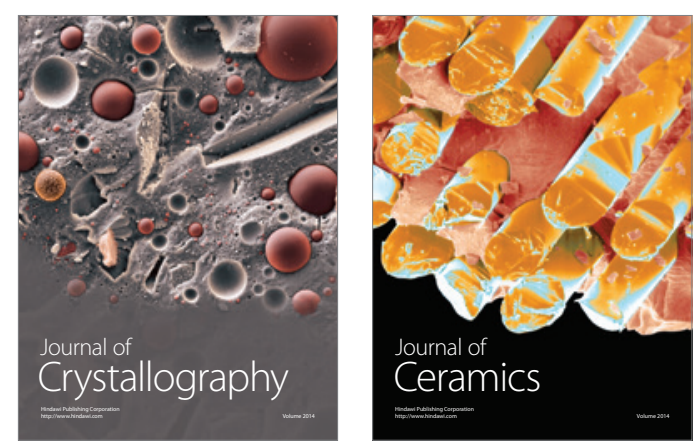
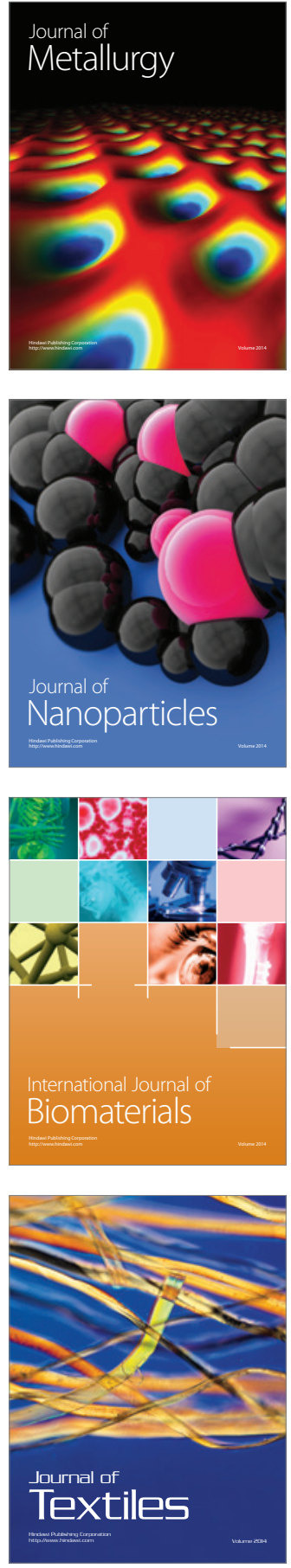